\title{
Antibiotic Prophylaxis in Elective Hand Surgery
}

\section{Profilaxis antibiótica en cirugía electiva de la mano}

\author{
Carolina Vasconcelos ${ }^{1}$ Marta Serra ${ }^{1}$ Rúben Nogueira ${ }^{1}$ Leonor do Carmo ${ }^{1}$ \\ ${ }^{1}$ Division of Plastic, Reconstructive and Aesthetic Surgery, \\ Department of Plastic, Reconstructive and Maxillo-Facial Surgery, \\ Hospital de Egas Moniz, Lisboa, Portugal \\ Rev Iberam Cir Mano 2017;45:89-93. \\ Address for correspondence Carolina Maria Braga de Vasconcelos, \\ Resident, Division of Plastic, Reconstructive and Aesthetic Surgery, \\ Department of Plastic, Reconstructive and Maxillo-Facial Surgery, \\ Hospital de Egas Moniz, Lisboa, Portugal \\ (e-mail: cmvasconcelos@gmail.com).
}

\begin{abstract}
Keywords

- hand surgery

- antibiotic prophylaxis

- infection

\section{Resumen}

Purpose Antibiotic prophylaxis decreases the rate of surgical site infection in a broad spectrum of surgical procedures. However, in patients undergoing elective hand surgery, there is evidence of lower efficacy, and its use might be related to the development of antimicrobial resistance. The side effects and higher health-related costs must also be taken into consideration. Our aim was to assess the efficacy of antibiotic prophylaxis in these procedures.

Material and methods A retrospective study was conducted including all patients who underwent clean, elective hand surgery lasting less than 30 minutes from January 1st 2014 to December 31st 2015 at our hospital. The demographic and surgery-related data were analyzed using the Statistical Package for the Social Sciences (SPSS, IBM Corp., Armonk, NY, US) software, version 23.0.

Results A total of 346 patients matched the study's inclusion criteria. The infection rate was of $1 \%$, and it was not influenced by gender, age or diabetes mellitus. Antibiotic prophylaxis was administered in $52 \%$ of the cases, and it had no effect on the decrease in the infection rate, even in the group of diabetic patients.

Conclusions Despite the inherent limitations of any retrospective study, our data analysis supports the fact that prophylactic antibiotic administration does not reduce the incidence of surgical site infection in clean, elective hand surgery that lasts less than 30 minutes, even in patients at risk.

Introducción La profilaxis antibiótica disminuye la tasa de infección quirúrgica en un amplio espectro de procedimientos. Sin embargo, en los pacientes sometidos a cirugía electiva de la mano, existe evidencia de una menor eficacia, y hay que considerar que su uso podría estar relacionado con el desarrollo de la resistencia a los antimicrobianos, los efectos secundarios y el mayor costo en salud. Nuestro objetivo fue evaluar la eficacia de la profilaxis antibiótica en estos procedimientos.

Material y métodos Se realizó un estudio retrospectivo que incluyó a todos los pacientes sometidos a cirugía de mano limpia y programada, con duración inferior a 30 minutos, desde el 1 de enero de 2014 al 31 de diciembre de 2015 en nuestro hospital. Los datos demográficos y quirúrgicos se analizaron mediante el programa Statistical Package for the Social Sciences (SPSS, IBM Corp., Armonk, NY, US), versión 23.0.
\end{abstract}

received

June 11,2017

accepted

September 25, 2017

published online

November 6, 2017 
Palabras Clave

- cirúgia de mano

- profilaxis antibiótica

- infección
Resultados Un total de 346 pacientes cumplió los criterios de inclusión en el estudio. La tasa de infección fue de $1 \%$, y no fue influenciada por el sexo, la edad, o diabetes mellitus. La profilaxis antibiótica se administró en el $52 \%$ de los casos, y no tuvo efecto sobre la disminución de la tasa de infección, incluso en el grupo de pacientes diabéticos.

Conclusiones A pesar de las limitaciones inherentes a cualquier estudio retrospectivo, nuestro análisis de datos apoya el hecho de que la administración profiláctica de antibióticos no reduce la incidencia de infección del sitio quirúrgico en cirugía de mano limpia y programada, con duración inferior a 30 minutos, incluso en pacientes de riesgo.

\section{Introduction}

The development of antibiotics and the proliferation of their use as a prophylactic measure have had a determining impact in the decrease in the risk of surgical site infection. Their efficacy is well-documented in many procedures, such as in colorectal surgery ${ }^{1}$ or in those procedures requiring alloplastic implants, ${ }^{2}$ resulting in an undoubtedly major contribution to lowering surgery-related morbidity and mortality.

However, in clean, elective hand surgery, infection rates are low, and they are most frequently limited to the superficial tissues, with deep wound infection being extremely rare. ${ }^{3}$ There is a fair amount of published evidence showing the lack of effect of prophylactic antibiotherapy in these procedures, ${ }^{4-6}$ particularly in carpal tunnel release, even in those patients with higher risk of postoperative infection, namely diabetic patients.

Besides the controversy of their indication, the indiscriminate use of antibiotics is not innocuous. Their widespread utilization leads to the development and proliferation of antimicrobial resistance, ${ }^{7}$ a global and increasing health problem, resulting in serious concerns regarding infection therapy, threatening the effective prevention and treatment of an ever-increasing range of hypervirulent pathogens. Furthermore, severe adverse effects (such as allergic or even anaphylactic reactions, as well as the potentially harmful Clostridium difficile infection ${ }^{8}$ ) may result from inadequate antibiotic administration, not to mention the higher health-related costs.

Despite the aforementioned facts and the existing evidence, some surgeons are still reluctant not to use antibiotic prophylaxis in these procedures, an attitude that might be explained by the paucity of studies performed on the Portuguese population, as well as the scarcity of established and approved protocols concerning this matter.

Our aim was to assess the efficacy of antibiotic prophylaxis in decreasing the rate of surgical-site infection in clean, elective, outpatient hand surgery lasting less than $30 \mathrm{mi}-$ nutes, and to establish guidelines to rationalize its use.

\section{Material and Methods}

In order to pursue the aforementioned goals, a retrospective study was performed in the Plastic Surgery Department at a hospital in Lisbon, Portugal, which included all patients who underwent elective, outpatient hand surgery lasting less than
30 minutes from January 1st 2014 to December 31st 2015. Only clean procedures (in which the surgical wound showed no signs of infection or inflammation, and was submitted to primary closure ${ }^{9}$ ) were included in the analysis. Patients who presented with suspicion of local or systemic infection, those who suffered traumatic injuries, and those submitted to procedures envolving implantable devices were excluded from the study population, as well as patients with incomplete medical records or with a follow-up period inferior to 30 days.

The patient records were reviewed, and the following data were collected: demographic factors (gender and age at the time of the procedure); medical history, namely the presence of diabetes mellitus; diagnosis requiring surgery; preoperative antibiotic prophylaxis administration; length of the procedure and type of operating room in which it was performed; postoperative infection or other complications; and therapy instituted to treat complications, as well as resulting sequelae. The demographic and surgery-related data were analyzed using the Statistical Package for the Social Sciences (SPSS, IBM Corp., Armonk, NY, US) software, version 23. The Pearson's Chi-Squared test and the Student's $t$-test were used for the nominal and continuous variables respectively, and p-values $<0.05$ were considered statistically significant.

\section{Results}

The characteristics of the study population are depicted in - Table 1. A total of 346 patients matched the study's inclusion criteria, and the majority of them were female (296 patients, $86 \%$ ), with an average age of 58.4 years. 245 patients (71\%) had a positive medical history, and $50(14 \%)$ of them were diabetic. The most frequent diagnosis requiring surgery was carpal tunnel syndrome (CTS; 211 patients; 61\%). Antibiotic prophylaxis (Cefazolin $2 \mathrm{~g}$, prior to tourniquet inflation) was administered in the preoperative period in 180 patients (52\%), with surgical interventions lasting on average 19.6 minutes. A total of 4 cases of surgical wound infection were reported, all of them only affecting the superficial layers, which resulted in an infection rate of $1 \%$. All cases were treated with oral antibiotic therapy, with complete resolution of the signs and symptoms within one week, and no sequelae were observed ( $\mathbf{-}$ Table $\mathbf{1}$ ).

The patients were initially divided into two groups: those who underwent antibiotic prophylaxis and those who did 
Table 1 Characteristics of the study population

\begin{tabular}{|c|c|}
\hline & $\begin{array}{l}\text { Patients } \\
(n=346)\end{array}$ \\
\hline \multicolumn{2}{|l|}{ Gender } \\
\hline Female & $296(86 \%)$ \\
\hline Male & $50(14 \%)$ \\
\hline \multicolumn{2}{|l|}{ Age (years) } \\
\hline$<21$ & $3(1 \%)$ \\
\hline $21-40$ & $32(9 \%)$ \\
\hline $41-60$ & $168(49 \%)$ \\
\hline $61-80$ & $117(34 \%)$ \\
\hline$>80$ & $26(7 \%)$ \\
\hline Average & 58.4 \\
\hline \multicolumn{2}{|l|}{ Positive medical history } \\
\hline Yes & $245(71 \%)$ \\
\hline No & $101(29 \%)$ \\
\hline \multicolumn{2}{|l|}{ Diabetes mellitus } \\
\hline Yes & $50(14 \%)$ \\
\hline No & $296(86 \%)$ \\
\hline \multicolumn{2}{|l|}{ Diagnosis } \\
\hline Carpal tunnel syndrome & $211(61 \%)$ \\
\hline Trigger finger & $68(19 \%)$ \\
\hline Dupuytren & $61(18 \%)$ \\
\hline Mass & $6(2 \%)$ \\
\hline \multicolumn{2}{|l|}{ Operating room } \\
\hline Outpatient & $226(65 \%)$ \\
\hline Minor procedures & $120(35 \%)$ \\
\hline \multicolumn{2}{|l|}{ Antibiotic prophylaxis } \\
\hline Yes & $180(52 \%)$ \\
\hline No & $166(48 \%)$ \\
\hline \multicolumn{2}{|l|}{ Length of the procedure } \\
\hline Average & 19.6 minutes \\
\hline \multicolumn{2}{|l|}{ Infection } \\
\hline Yes & $4(1 \%)$ \\
\hline No & 342 (99\%) \\
\hline
\end{tabular}

not. There were no significant differences between the groups in terms of gender or age; patients with a positive medical history received more antibiotics statistically, but preoperative antibiotics were administered to patients with or without diabetes mellitus in a similar way. The procedures were either performed in the outpatient or in the minor procedures operating room, and in the former the percentage of antibiotic prophylaxis was significantly higher (180 of the 226 patients $(80 \%)$ versus none of the patients $(0 \%)$ in the minor procedures operating room). Two cases of infection were reported in each context (-Table 2 ).

The infection rate was not statistically different with resepect to the patients' gender, age, positive medical history,
Table 2 Characteristics of the study population according to antibiotic prophylaxis

\begin{tabular}{|c|c|c|c|}
\hline & $\begin{array}{l}\text { Prophylaxis } \\
(n=180)\end{array}$ & $\begin{array}{l}\text { No prophylaxis } \\
(n=166)\end{array}$ & $p$-value \\
\hline \multicolumn{4}{|l|}{ Gender } \\
\hline Female & $156(53 \%)$ & $140(47 \%)$ & \multirow[t]{2}{*}{$0.538^{*}$} \\
\hline Male & $24(48 \%)$ & $26(52 \%)$ & \\
\hline $\begin{array}{l}\text { Age } \\
\text { (average, years) }\end{array}$ & 58.4 & 58.5 & $0.931^{\S}$ \\
\hline \multicolumn{4}{|c|}{ Positive medical history } \\
\hline Yes & $142(58 \%)$ & 103 (42\%) & \multirow[t]{2}{*}{$0.001^{*}$} \\
\hline No & $38(38 \%)$ & $63(62 \%)$ & \\
\hline \multicolumn{4}{|l|}{ Diabetes mellitus } \\
\hline Yes & $27(54 \%)$ & $23(46 \%)$ & \multirow[t]{2}{*}{$0.762^{*}$} \\
\hline No & $153(52 \%)$ & $143(48 \%)$ & \\
\hline \multicolumn{4}{|l|}{ Diagnosis } \\
\hline $\begin{array}{l}\text { Carpal tunnel } \\
\text { syndrome }\end{array}$ & $145(69 \%)$ & $66(31 \%)$ & \multirow[t]{4}{*}{$0.000^{*}$} \\
\hline Trigger finger & $20(29 \%)$ & $48(71 \%)$ & \\
\hline Dupuytren & $12(20 \%)$ & $49(80 \%)$ & \\
\hline Mass & $3(50 \%)$ & $3(50 \%)$ & \\
\hline \multicolumn{4}{|l|}{ Operating room } \\
\hline Outpatient & $180(80 \%)$ & $46(20 \%)$ & \multirow[t]{2}{*}{$0.000^{*}$} \\
\hline $\begin{array}{l}\text { Minor } \\
\text { procedures }\end{array}$ & $0(0 \%)$ & $120(100 \%)$ & \\
\hline \multicolumn{4}{|l|}{ Infection } \\
\hline Yes & $2(50 \%)$ & $2(50 \%)$ & \multirow[t]{2}{*}{$0.935^{*}$} \\
\hline No & $178(52 \%)$ & $164(48 \%)$ & \\
\hline
\end{tabular}

Notes: *Pearson's Chi-Squared test; §Student's t-test.

diabetes mellitus, or the operating room in which the procedure took place. More importantly, antibiotic prophylaxis had no statistically significant influence on the occurrence of postoperative infection ( 2 reported cases of infection received prophylaxis, and the other 2 did not; - Table 3 ).

A statistically significant relationship was observed between the diagnosis requiring surgery and the administration of preoperative prophylaxis (145 of the 211 patients (69\%) with CTS versus 35 of the 135 (26\%) with a diagnosis other than CTS received prophylaxis), and between the diagnosis and the occurrence of infection (all of the patients with infections belonged to the non-CTS diagnosis group; - Table 4). However, even when we performed a subgroup analysis only including those patients with a diagnosis other than CTS (all of whom had infections), the antibiotic prophylaxis still had no influence on the infection rate ( $\mathbf{- T a b l e ~} \mathbf{5}$ ).

The diagnosis of diabetes mellitus is a proven risk factor for infection in many contexts. However, in our study, its presence did not influence the infection rate (surprisingly, only 1 of the patients with postoperative infection was diabetic, while the other 3 were not; - Table 6 ). 
Table 3 Characteristics of the study population according to infection

\begin{tabular}{|c|c|c|c|}
\hline & $\begin{array}{l}\text { Infection } \\
(n=4)\end{array}$ & $\begin{array}{l}\text { No infection } \\
(n=342)\end{array}$ & $p$-value \\
\hline \multicolumn{4}{|l|}{ Gender } \\
\hline Female & $3(1 \%)$ & 293 (99\%) & \multirow[t]{2}{*}{$0.546^{*}$} \\
\hline Male & $1(2 \%)$ & $49(98 \%)$ & \\
\hline $\begin{array}{l}\text { Age } \\
\text { (average, years) }\end{array}$ & 62.5 & 58.4 & $0.578^{\S}$ \\
\hline \multicolumn{4}{|c|}{ Positive medical history } \\
\hline Yes & $2(1 \%)$ & $243(99 \%)$ & \multirow[t]{2}{*}{$0.357^{*}$} \\
\hline No & $2(2 \%)$ & 99 (98\%) & \\
\hline \multicolumn{4}{|l|}{ Diabetes mellitus } \\
\hline Yes & $1(2 \%)$ & $49(98 \%)$ & \multirow[t]{2}{*}{$0.546^{*}$} \\
\hline No & $3(1 \%)$ & 293 (99\%) & \\
\hline \multicolumn{4}{|l|}{ Diagnosis } \\
\hline $\begin{array}{l}\text { Carpal tunnel } \\
\text { syndrome }\end{array}$ & $0(0 \%)$ & $211(100 \%)$ & \multirow[t]{4}{*}{$0.001^{*}$} \\
\hline Trigger finger & $1(2 \%)$ & 67 (98\%) & \\
\hline Dupuytren & $2(3 \%)$ & 59 (97\%) & \\
\hline Mass & $1(17 \%)$ & $5(83 \%)$ & \\
\hline \multicolumn{4}{|l|}{ Operating room } \\
\hline Outpatient & $2(1 \%)$ & 224 (99\%) & \multirow[t]{2}{*}{$0.517^{*}$} \\
\hline $\begin{array}{l}\text { Minor } \\
\text { procedures }\end{array}$ & $2(2 \%)$ & $118(98 \%)$ & \\
\hline \multicolumn{4}{|c|}{ Antibiotic prophylaxis } \\
\hline Yes & $2(1 \%)$ & 178 (99\%) & \multirow[t]{2}{*}{$0.935^{*}$} \\
\hline No & $2(1 \%)$ & 164 (99\%) & \\
\hline
\end{tabular}

Notes: *Pearson's Chi-Squared test; §Student's t-test.

Table 4 Diagnosis-specific characteristics of the study population

\begin{tabular}{|c|c|c|c|}
\hline & $\begin{array}{l}\text { CTS } \\
(n=211)\end{array}$ & $\begin{array}{l}\text { Non-CTS } \\
(n=135)\end{array}$ & $p$-value \\
\hline \multicolumn{4}{|c|}{ Antibiotic prophylaxis } \\
\hline Yes & 145 (69\%) & $35(26 \%)$ & \multirow[t]{2}{*}{$0.000^{*}$} \\
\hline No & $66(31 \%)$ & $100(74 \%)$ & \\
\hline \multicolumn{4}{|c|}{ Infection } \\
\hline Yes & $0(0 \%)$ & $4(3 \%)$ & \multirow[t]{2}{*}{$0.012^{*}$} \\
\hline No & $211(100 \%)$ & $131(97 \%)$ & \\
\hline
\end{tabular}

Abbreviation: CTS, carpal tunnel syndrome.

Note: *Pearson's Chi-Squared test.

\section{Discussion}

The demographic characteristics of our study population match the epidemiology reported in the literature: the majority of our patients were female, aged between 41 and 60 years old; CTS is known to be more prevalent in women between 45 and 59 years old. ${ }^{10,11}$
Table 5 Efficacy analysis of antibiotic prophylaxis in cases of diagnosis other than carpal tunnel syndrome

\begin{tabular}{|c|l|l|l|}
\hline & $\begin{array}{l}\text { Infection } \\
(\boldsymbol{n}=\mathbf{4})\end{array}$ & $\begin{array}{l}\text { No infection } \\
(\boldsymbol{n}=\mathbf{1 3 1})\end{array}$ & -value \\
\hline \multicolumn{3}{|c|}{ Antibiotic prophylaxis } \\
\cline { 1 - 3 } Yes & $2(6 \%)$ & $33(94 \%)$ & \\
\hline No & $2(2 \%)$ & $98(98 \%)$ & \\
\hline
\end{tabular}

Note: *Pearson's Chi-Squared test.

Table 6 Characteristics of the study population according to diabetes mellitus

\begin{tabular}{|c|c|c|c|}
\hline & $\begin{array}{l}\text { Diabetic } \\
(n=50)\end{array}$ & $\begin{array}{l}\text { Non-diabetic } \\
(n=296)\end{array}$ & $p$-value \\
\hline \multicolumn{4}{|l|}{ Gender } \\
\hline Female & $40(14 \%)$ & 256 (86\%) & \multirow[t]{2}{*}{$0.228^{*}$} \\
\hline Male & $10(20 \%)$ & $40(80 \%)$ & \\
\hline Age (average, years) & 64.6 & 57.4 & $0.000^{\S}$ \\
\hline \multicolumn{4}{|l|}{ Diagnosis } \\
\hline $\begin{array}{l}\text { Carpal tunnel } \\
\text { syndrome }\end{array}$ & $28(13 \%)$ & $183(87 \%)$ & \multirow[t]{4}{*}{$0.165^{*}$} \\
\hline Trigger finger & $14(21 \%)$ & $54(79 \%)$ & \\
\hline Dupuytren & $6(10 \%)$ & $55(90 \%)$ & \\
\hline Mass & $2(33 \%)$ & $4(67 \%)$ & \\
\hline \multicolumn{4}{|l|}{ Operating room } \\
\hline Outpatient & $34(15 \%)$ & $192(85 \%)$ & \multirow[t]{2}{*}{$0.667^{*}$} \\
\hline Minor procedures & $16(13 \%)$ & $104(87 \%)$ & \\
\hline \multicolumn{4}{|l|}{ Antibiotic prophylaxis } \\
\hline Yes & $27(15 \%)$ & $153(85 \%)$ & \multirow[t]{2}{*}{$0.762^{*}$} \\
\hline No & $23(14 \%)$ & $143(86 \%)$ & \\
\hline \multicolumn{4}{|l|}{ Infection } \\
\hline Yes & $1(25 \%)$ & $3(75 \%)$ & \multirow[t]{2}{*}{$0.546^{*}$} \\
\hline No & 49 (14\%) & $293(86 \%)$ & \\
\hline
\end{tabular}

Notes: *Pearson’s Chi-Squared test; ${ }^{\S}$ Student's t-test.

In the absence of established protocols concerning elective hand surgery at our institution, the decision to administer preoperative antibiotic prophylaxis is case-dependent; the previous medical history, the specific procedure to perform and its expected length all play a role in this verdict. Overall, 180 patients (52\%) underwent prophylaxis, and the rates were even higher in the group of patients with positive medical history (142 patients out of $245,58 \%$ ) particularly those with diabetes mellitus ( 27 patients out of $50,54 \%$ ). The authors found these results to be extremely high, considering the current published evidence, and hypothesized that these therapeutic attitudes are based on an extrapolation from the fact that prophylactic antibiotics have been shown to prevent surgical site infection after many gastrointestinal and orthopedic procedures. ${ }^{1,2}$ 
There is great discrepancy between the prophylaxis rate in the different types of operating rooms, which can be easily explained based on the specific characteristics of each one. In the minor procedures room, the plastic surgeon has the sole responsibility for the decision, and antibiotics were not administered to any of the patients. However, in the outpatient room, an anesthesiologist is present and often performs some kind of locoregional anesthesia technique and participates in the decision regarding the antibiotic prophylaxis, which at least partially explains the discrepancy observed. We might also conjecture that patients with a positive medical history are more often operated on in the outpatient room, a factor that can also influence the higher rate of antibiotic prophylaxis in this setting.

According to the diagnosis requiring surgery, statistically significant differences were observed in the prophylaxis administration and in the infection rates, so the authors performed a subgroup analysis to assess the efficacy of the antibiotics in both groups. In the CTS group, 69\% of the patients underwent prophylaxis, while $31 \%$ did not, and none of them had surgical site infections, which is in accordance with the published evidence on this specific context. ${ }^{6}$ In the non-CTS group, 35 patients (26\%) underwent prophylaxis, and 4 patients (3\%) had infections, but even in this subgroup, the administration of prophylactic antibiotics was not shown to significantly reduce the incidence of surgical site infection.

A total of 4 cases of infection were reported ( $1 \%$ of the surgical procedures), all of them superficial infections according to the Infection Control Practices Advisory Committee ${ }^{9}$ guidelines: infections that occur within 30 days after the operative procedure and involve only the skin and subcutaneous tissue of the incision. None of the patients required hospital admission or intravenous therapy, and no sequelae were observed.

The occurrence of infection was not significantly influenced by the patients' age or gender, positive medical history or diabetes mellitus (in contrast to some published studies ${ }^{5}$ ), or the type of operating room where the procedure took place. Antibiotic prophylaxis did not influence the occurrence of infection, even in diabetic patients, who are classically considered a higher-risk group, in accordance to the majority of the published evidence. ${ }^{4-6}$

As this was a retrospective study, some limitations should not be overlooked. First of all, there was no patient randomization concerning the administration of the prophylaxis, with this decision being left solely to the surgeon (or surgeon/anesthesiologist team), creating a difficult bias to overcome. Furthermore, the overall infection rate after CTS release was low (4 patients; $1 \%$ ), precluding the independent analysis of the variables, thus weakening the statistical power of the evidence obtained. However, despite these limitations, our results are in line with the current evidence. The authors recognize the need to conduct further studies, preferably randomized and with a prospective design, in order to strengthen the level of evidence achieved.

\section{Conclusions}

Despite the inherent limitations of any retrospective study, our data analysis supports the fact that prophylactic antibiotic administration does not reduce the incidence of surgical site infection in clean, elective hand surgery lasting less than 30 minutes, even in patients at risk. With this evidence in mind, the authors believe that an informed discussion should be held concerning this matter, and protocols should be established to rationalize antibiotic use in this context, even more so considering the eventual risks associated with its widespread and inadequate utilization, particularly the increase in antimicrobial resistance.

Conflicts of Interest

Authors declare no conflicts of interest.

\section{References}

1 Nelson RL, Gladman E, Barbateskovic M. Antimicrobial prophylaxis for colorectal surgery. Cochrane Database Syst Rev 2014; 5(05):CD001181

2 Marculescu CE, Osmon DR. Antibiotic prophylaxis in orthopedic prosthetic surgery. Infect Dis Clin North Am 2005;19(04): 931-946

3 Hanssen AD, Amadio PC, DeSilva SP, Ilstrup DM. Deep postoperative wound infection after carpal tunnel release. J Hand Surg Am 1989;14(05):869-873

4 Tosti R, Fowler J, Dwyer J, Maltenfort M, Thoder JJ, Ilyas AM. Is antibiotic prophylaxis necessary in elective soft tissue hand surgery? Orthopedics 2012;35(06):e829-e833

5 Bykowski MR, Sivak WN, Cray J, Buterbaugh G, Imbriglia JE, Lee WP. Assessing the impact of antibiotic prophylaxis in outpatient elective hand surgery: a single-center, retrospective review of 8,850 cases. J Hand Surg Am 2011;36(11):1741-1747

6 Harness NG, Inacio MC, Pfeil FF, Paxton LW. Rate of infection after carpal tunnel release surgery and effect of antibiotic prophylaxis. J Hand Surg Am 2010;35(02):189-196

7 Marston HD, Dixon DM, Knisely JM, Palmore TN, Fauci AS. Antimicrobial Resistance. JAMA 2016;316(11):1193-1204

8 Carignan A, Allard C, Pépin J, Cossette B, Nault V, Valiquette L. Risk of Clostridium difficile infection after perioperative antibacterial prophylaxis before and during an outbreak of infection due to a hypervirulent strain. Clin Infect Dis 2008;46(12):1838-1843

9 Mangram AJ, Horan TC, Pearson ML, Silver LC, Jarvis WR; Hospital Infection Control Practices Advisory Committee. Guideline for prevention of surgical site infection, 1999. Infect Control Hosp Epidemiol 1999;20(04):250-278, quiz 279-280

10 Mondelli M, Giannini F, Giacchi M. Carpal tunnel syndrome incidence in a general population. Neurology 2002;58(02):289-294

11 Stevens JC, Sun S, Beard CM, O'Fallon WM, Kurland LT. Carpal tunnel syndrome in Rochester, Minnesota, 1961 to 1980 . Neurology 1988;38(01):134-138 